\title{
The Arab Spring Protests and Concurrent Disability Protests: Social Movement Spillover or Spurious Relationship?
}

\author{
SHARON N. BARNARTT \\ Gallaudet University, USA
}

\begin{abstract}
Protests from different social movements sometimes coincide, but does that mean that one movement is influencing the other and increasing its "action mobilization," or are different sets of factors causing the coincident protests? This paper examines that question in reference to two sets of coincident protests: those of people with disabilities and those of the pro-Democracy protests of 2011. It shows that, although disability protests did not start at the same time as the pro-Democracy protests, a number happened during and after, and in close physical proximity to, those protests. Neither set of protests acknowledged or referred to the other. While it is likely that a new law in Egypt and the UN Convention on the Rights of Persons with Disabilities were among the mobilizing factors for people with disabilities, it also appears that the language of "rights" began to diffuse from the pro-Democracy protests to the disability protests.
\end{abstract}

\section{Introduction}

Many protests have occurred in Egypt in the period from early 2010 to2011. Some of these were the pro-democracy protests which were widely publicized and considered to be part of the "Arab Spring." Others were not widely publicized. They related to disability and were conducted by disabled people. This paper analyzes the coincidence of the pro-Democracy and disability protests before, during, and after the period called the Arab Spring.

Many scholars have addressed questions related to protest in Egypt, its frequency, its relationship to the political structure or process, the different types of protest, and the results of protests for subsequent political processes 
(e.g. Glover, 2010; Beinin, 2009). Most of these discussions were from a political science point of view, and none of the materials that this researcher could find discuss disability-related protests, except for Glover (2010), who mentions them in passing.

Disability is not a small problem in Egypt, a similarity shared by other developing countries (or developed countries, for that matter). Estimates of the number of people with disabilities vary from seven million (Egyptian people with disabilities must not be forgotten, 2011) to 10 million (Disabled protest in Egypt continues, 2011) people with disabilities in Egypt. However, since many people openly discuss the fact that families hide their disabled members, in part to assure the marriageability of other family members (Reynolds, 2006), this is likely to be an underestimation. There is inadequate special education or integrated education. Although this is also true for children without disabilities, the ratio is 1 school per 454 non-disabled children as opposed to 1 specialized school per 44,850 disabled children (Mahmoud, 2012). There is social and cultural discrimination as well as economic and political inequality. Despite these factors, little has been heard in the protest arena from people with disabilities until fairly recently.

Many scholars have written about disability protests or movements in specific countries. Scholars who have investigated disability protests in one country include Barnartt and Scotch (2000) about the United States, Barral (2007) about France, Bugg (2001) about South Africa, Hayashi and Okuhira about Japan (2001), Heyl (1998) and Heyer (2002a) about Germany, Tucker (2007) about Jamaica, and Oliver $(1990,1996)$ about the UK. Some scholars have compared disability protests in two or a small number of countries (Barnartt, 2008; Barnartt \& Rotman, 2007; Heyer, 2002b; Olson, Penna, \& Veith, 2004). However, there has been no research that this author could find in English about disability protests in Egypt.

This paper asks what type of relationship existed between disability protests and the concurrently occurring pro-Democracy protests. Did the latter protests in any way cause the disability protests, or were the sets or protests independently caused?

\section{Theoretical Framework}

Protests, those "in your face, in the street" demands for change, happen for many reasons. Many answers have been proposed to the question, "What types of social conditions facilitate the growth of protests and social movements?" (McAdam, McCarthy, \& Zald, 1988). The presence of grievances or inequalities is necessary but not sufficient, as are a number of other conditions. These include social structural strain (Smelser, 1962), inequities in access to resources (McCarthy \& Zald, 1973), the presence of existing social networks (Morris, 1984), the absence of competing solidarities, the presence of aggrieved and otherwise powerless people (Lipsky, 1968; Piven \& Cloward, 1979), relative deprivation (Davies, 1963), changes in the 
structure of political opportunities (Tarrow, 1989), lack of repressive social control, suddenly imposed grievances (Opp, 1988), the presence of formal organizations or informal groups (McAdam, 1982; McAdam, McCarthy, \& Zald, 1988; Morris, 1984), and the existence of collective action frames that fit into existing cultural assumptions (Snow \& Benford, 1988, 1992; Snow, Rochford, Worden, \& Benford, 1986).Protests are not the only, or even the most radical, actions that social movements can take. This is especially true across cultures. For example, disability rights organizations in Japan started their own personal attendant care programs in the 1980s (Hayashi \& Okuhira, 2001). In the United States, that might not have seemed to be a radical action on par with a protest, but, in Japan, at that time, it was pioneering and probably paradigm-changing. However, protests are the only type of tactic analyzed here.

Analysis of any set of protests raises the question of mobilization. How did the participants become mobilized enough to be "in the streets?" Generally, disabled people have tended not to mobilize for protests, for reasons related to the logistical difficulties of getting to and participating in protests, the lack of a collective consciousness, and their separation into impairment-related groups with little in common with other groups (Scotch, 1988). Yet, in Egypt, disabled people, who had not been reported to have fomented protests very often before that, did engage in protests in 2010 and 2011 with or near the pro-Democracy protesters.

The central question of this paper is whether the pro-Democracy protests caused the disability protests or whether the sets of protests were caused by different third factors. If two events occur simultaneously, there are three possible explanations. One is that the first one causes the second one. The second is that they are both caused by the same external variables. The third is that each is caused by a different external variable. Let us examine these possibilities.

Based upon the fact that social movements do not appear in a vacuum but rather often appear in clusters, causally related to each other, McAdam (1995) distinguishes between "initiator" and "spin-off" movements, while Meyer and Whittier (1994) talk about social movement "spillover." For both, one social movement precedes, and is causally related to, the later one. McAdam emphasizes mechanisms of diffusion, network ties, organizational structures, and attributions of similarity in the transition from the initiator to the spin-off movement. Meyer and Whittier emphasize frame alignment, tactical repertoires, overlapping leadership or personnel, and changes in the political opportunity structure as mechanisms by which spillovers happen.

Simultaneous protests could also be caused by some common third factor. These might be spillovers from prior movements or changes in factors which themselves increase social movement activity in all sectors. These could include changes in the social structure, culture, or political opportunity structure. In this case, in statistical terms, the third variables are spurious. The third variable is causing both of the simultaneously occurring protests.

Another possibility is that there might be different factors or variables 
which are causing each of the sets of protests. These could include changes in the specific demands, organizational structure, consciousness and other aspects of the social movement of which the protest is a part. Or they could include changes in several aspects of the society. In this case the simultaneous protests are parallel events which are not linked to each other but to other, different, variables. This paper attempts to determine which type of relationship was at work in this situation.

\section{Methodology}

This paper is part of an on-going event history analysis of disability-related protests which have occurred since 1970. Awareness of the simultaneity of the disability protests and the Arab Spring protests was a serendipitous result of this research. Reports of protests were collected from online newspapers, using print indices and Lexus-Nexus as searching tools. There are, of course, problems in depending upon newspaper reports of protests. One problem which occurs in locating cross-cultural cases of protest relates to language. While many countries now have newspapers in English, on line or in print, not all do, and for many it is a very recent phenomenon. Thus the reports do not always go back very far. Additionally, McCarthy, McPhail, \& Smith, (1996), Mueller (1997), and Snyder \& Kelly (1977) argue that media reports always substantially under-represent protests. They show that media reports are biased towards covering more disruptive protests - those which are longer, larger, and more violent. In general, more disruptive protests are more likely to be receive newspaper coverage than are less disruptive protests (Barnartt and Scotch, 2000).

The data reported here are based upon the social and cultural context of US protests, even though, in other countries, activities such as petition drives may be non-normative and therefore do constitute protests (Kriesi, Koopmans, Duyvendak, \& Guigni, 1997), voter registration drives, lobbying, fund-raising, petitions, or lawsuits were not defined as constituting protests in the US and so information about them was not gathered. Additionally, even though an event may be similar (e.g. people marching down a street holding banners and placards), the cultural and political meanings, including the interpretation of the threat level posed and the degree of acceptance of the tactics, may be completely different. This paper does not attempt to assess the meanings of the protests within the Egyptian context but to examine the relationships between the two sets of protests. This paper attempts to analyze protests within the Egyptian context but with these caveats. Other types of activities which would be viewed as being protests by disabled people in Egypt may have occurred at the same time, but protests fitting the US definition will be the focus of this paper. 


\section{Results}

The first disability protest this researcher could find in the English language newspapers occurred in December 1996. In this protest, approximately 3000 students protested the expulsions of about 300 students who were reported to have falsified their applications (to a special program which exempted handicapped students from requirements applied to other students) or to have been "not fully handicapped." The students chanted anti-government slogans and threw stones at police; the police responded by arresting some of them ("Egyptian Students Demonstrate," 1996.)

The protests continued for more than a week. On the second day, the police used tear gas against the protesters ("Egyptian Government Bows," 1996.) After negative publicity from a number of sources, the government gave in and announced that all handicapped students would be admitted to government-run universities, "regardless of the degree of handicap."

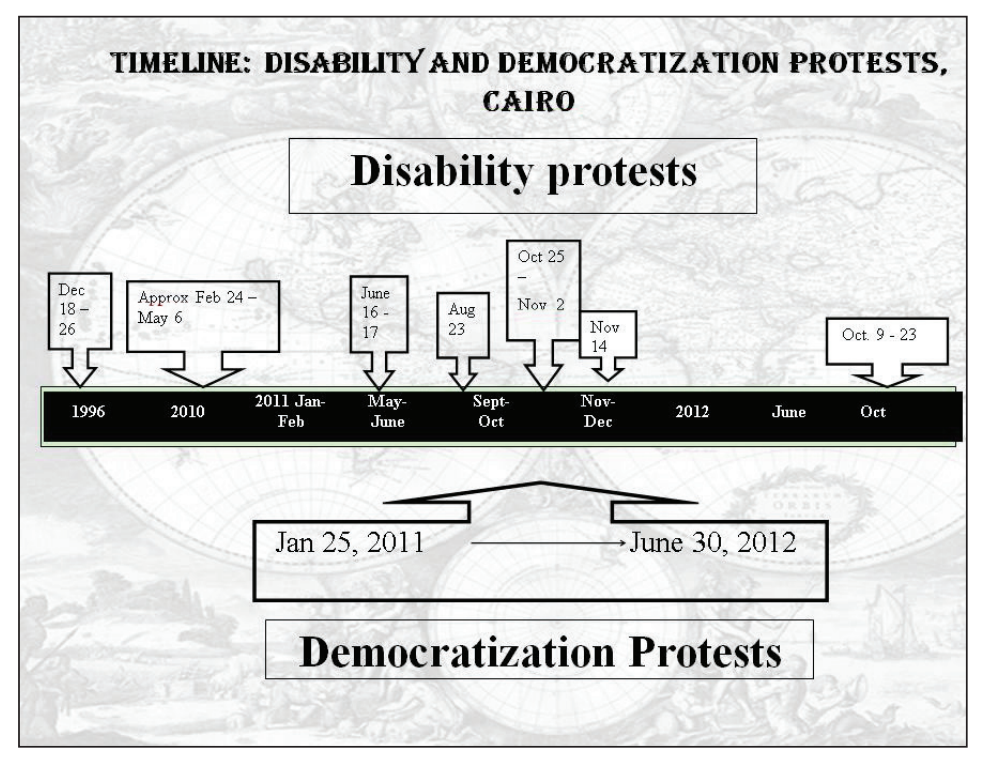

Figure 1

The second set of protests began in February, 2010, and continued through May 6 of that year (Salam, 2010; Salem, 2010). ${ }^{1}$ A group of disabled protesters who were interviewed on April 30 said they had been there for 47 days by that time. Having set up a tent city, they were part of a group described as factory workers, government workers, employees of a telephone company, and employees of a yarn factory. All were banging pots, pans, and bottles and chanting, demanding jobs, housing, and better incomes (Slackman, 2010). Mahmoud (2012) reported that several hundred disabled people participated in these protests. 
The third protest, which began on June 17, 2011, was the first which actually occurred during the pro-Democracy protests. This two-day protest demanded that the government "preserve and protect their rights and help them get jobs in the ministries and private sector" ("Disabled Protest in Egypt," 2011). Protesters were quoted as stressing their right to get a job, their need for more training programs and demanding the enforcement of a 2010 law which mandated that $5 \%$ of jobs be given to disabled people. This is the first time that the words "right" or "rights" appeared in a newspaper article.

The fourth protest began on October 25, 2011 and continued, off and on, for 6 days. It began with a sit-in in front of the Egyptian Parliament building, but it expanded to include blocking a major street and the threat by some protesters to set themselves on fire (one protester had already doused himself with gasoline before police intervened). At various times during this protest, other groups, including hospital workers and oil company workers, were protesting on the same street in close proximity to the disabled protesters ("Famous Streets," 2011). Demands in this protest included "the provision of job opportunities through government schemes, an increase in the quotas for hiring disabled people into government service from five to 10 percent, the provisions of transportation capable of accommodating people with disabilities, and free apartments for disabled married couples (Ismail, 2011).

About two weeks later, on November 14, disabled protesters blocked a large, popular road, holding up banners as police and people passing in cars watched them. An article in the Egyptian Gazette entitled "Helplessness is the Keyword" (2011) suggests that this was one of many protests which had been held in this location from "a feeling of helplessness." In particular, this time the protesters held up a banner reading "The Revolution of the Disabled" in order to protest the "government's disregard of their suffering."

Disability protests did not cease with the installation of the new government of Mohammed Morsi. One short protest occurred in Alexandria in June, 2012 (Elshami, 2012), and a long protest occurred in Cairo from the $9^{\text {th }}$ to the $23^{\text {rd }}$ of October, 2012. The latter initially had similar demands related to jobs and housing, but, after clashes with police left some demonstrators injured, the protest focus shifted to the lack of freedom to protest.

Much has been written about the pro-Democracy protests which occurred in Egypt at the same time as those protests called "the Arab Spring." The protests began on January 25, 2011, and continued until June 30, 2012 in Cairo. Demands initially focused on the overthrow of Mubarak, who resigned in February, 2011. Subsequent demands called for various aspects of democracy, including open elections. The first round of parliamentary elections occurred in November, 2011. Thus three of the disability protests occurred at the same time as the democratization protests, although two had occurred earlier [and several, some not shown here, have occurred since.] 


\section{Discussion}

Protests have become ubiquitous in advanced industrialized societies (Meyer \& Tarrow, 1998). However, protests are not new in Egypt either. Rather, as Arafa (2011) points out, there have been protests in Egypt since as early as 724 CE. Anderson (2011) begins by describing big protests that occurred in 1919 which sound quite similar to those in 2011.

More recently, Beinin (2009) points out that, by his estimation, over 2 million people participated in 2623 factory occupations, strikes, demonstrations or other types of collective actions between 1998 and 2008. He notes:

During the strike waves of 1984-89 and in the early 1990s, Egypt experienced 25-80 collective actions a year. From 1998 to 2003, this increased to an average of 118 workers' collective actions a year. In 2004 there were 265 collective actions - more than double the 1998-2003 average. (2009, p. 450)

Most of these actions were conducted by workers, especially those in the textile industry. As in many other countries, many textile workers are women, and this was true among these protesters, also. Some of the actions were strikes which were quite large and quite successful (Rowles \& Stretcher, 2011).

Beinin (2009, p. 454) also notes that grievances other than those related to labour situations began to emerge around the time of the second Palestinian Intifada and the 2003 invasion of Iraq. Militancy among civil servants and educational personnel began to emerge. In fact, he claims that a culture of protest was inculcated around this time which led to the consciousness of citizenship and rights which had not shown up during the prior protests. Glover (2010) echoes Beinin when she says that "the Egyptian street has re-emerged as the site of contention, and that protests are an everyday occurrence" (p. 2) This "normalization of protest" emerged in the early 2000s, and has "opened up a political space to be used by many" (p. 3). Olesen (2005) argues that the changes in the focus of protests from workers' issues to democracy issues show the emergence of the "latent master frame of democracy," and he argues that this was spread by globalization. If this is the case, it suggests that the two sets of protests were at least partially caused by different external factors, since the disability protesters lagged behind the pro-Democracy protesters in their use of this frame. Until the latest of the protests, the disability protests had not used the "latent master frame of democracy." Rather, when their protests began, their demands were for services related to one specific situation. By 2011, the protests were beginning to use the frame of rights, but the rights they demanded were a mixture of what Americans would call services and what they would call rights (Pfeiffer, 1988). The protests demanded more jobs (services), accessible transportation (rights) and free housing (services). ${ }^{2}$ It was not until late in 2011 that the disability protests were more aligned with the pro-Democracy frame when they demanded accessible voting places. 


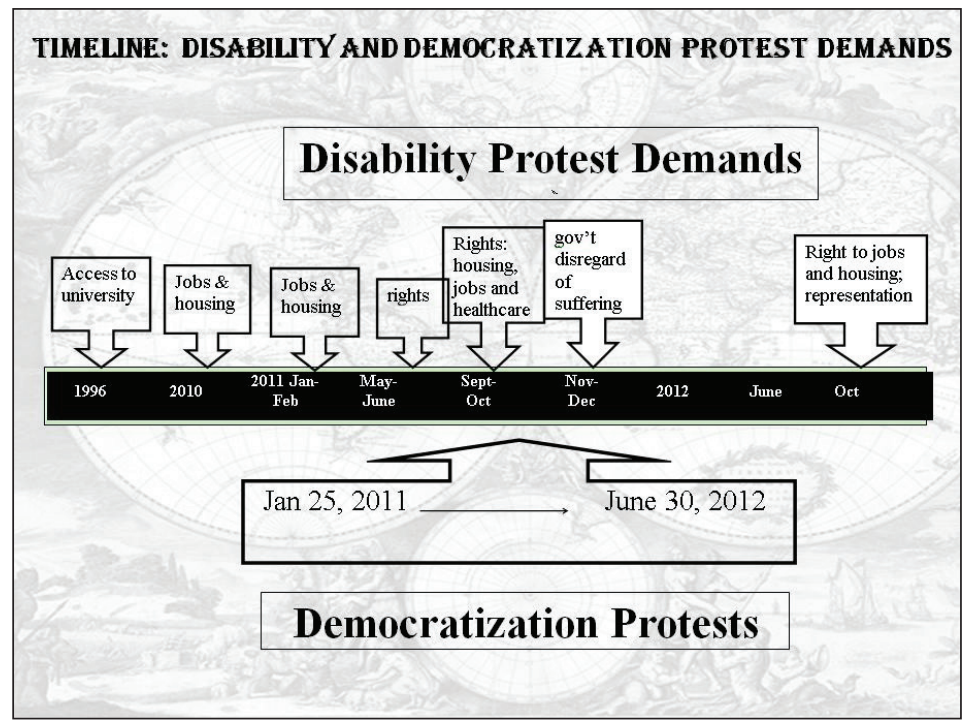

Figure 2

Klandermans $(1984 ; 1988)$ argued that beliefs, which he calls consensus mobilization, exist before social movement actions, which he calls action mobilization. Barnartt (1994) argued that sometimes the actions do come first, and then beliefs or ideologies develop. Sometimes action mobilization will occur before the social movement has a "frame," let alone a clearly articulated ideology. What we see here is a case of this. People with grievances [i.e. disabled people], in a society in which protest was common, took to the streets. They first protested about their specific grievances, and then later began appropriate a frame ["rights"], from other apparently successful protests, with which to align what they wanted with the cultural discourse of the society. Only in the most recent protests did their frame begin to align with that used in the pro-Democracy protests.

While at this time there was an increasing climate of, and rhetoric about, rights and citizenship in the general culture in Egypt, there was another specific change for disabled people there. In 2010, Egypt had passed a law requiring that five percent of jobs in both the public and private sectors be allocated to people with disabilities ("Disabled protest in Egypt continues," 2011), with jail sentences and fines possible for those who refused to hire disabled people. Additionally, Egypt had ratified the UN Convention on the Rights of Persons with Disabilities in 2008. This meant that there were now two legal successes for people with disabilities, in addition to the success garnered by the 1996 protest. In line with the idea of a "revolution of rising expectations" (Davies, 1963), people with disabilities began to expect, and ask for, more than they previously had. If nothing else, they wanted the law regarding employment to be enforced so that people actually got the jobs which were legally promised to them.

There was little reference within the newspaper coverage of disability 
protesters reacting to the pro-Democracy protests or protesters. No one was quoted as saying, for example, "We saw those people on the streets getting what they wanted, so we decided to protest, too." Although, logically, the omission cannot be used to support an argument of commission, it seems as if someone would have said that if it had been true. So, it is not clear that the larger non-disabled protests were the genesis of the smaller, disabilityrelated ones. ${ }^{3}$ Except in the case of the 1996 protest, it did not appear that pro-Democracy protesters joined or assisted in the disability-related protests. It is not even clear to what extent the pro-Democracy protesters were aware of these concurrent protests, and there is no evidence that they attempted to make use of the disability protests in order to gain more influence or to produce more disruption.

Rather, the disability protesters appear to have been affected by the other types of changes mentioned above. Neither group expressed hope that it would gain strength from the presence of the other, although the disabled protesters did gain one thing from their contemporaneous protesters. That one thing, which may have "spilled over" from the pro-Democracy protests, was the language of rights. As noted above, that language did not appear until it was used in articles about those disability protests which occurred during the proDemocracy protests. Because the language was used in newspaper articles, we cannot be sure whether it was protest participants or the journalists who actually used the language of rights. But several articles did quote protesters using that language. That language may also have percolated down from the UN Convention.

If the language of rights did spill over from the pro-Democracy protests, it was a significant change in discourse from the earlier protests. In some societies, such as Germany, there is no civil rights tradition or frame (Heyer, $2002 a$, p. 726). Frames for disability most often are related to "charity" (Scotch, 1984), although they may also include slogans such as "Disability does not mean inability," as used in Zimbabwe in the 1990s (Barnartt, 1992). Elshami (2012) indicates that the most common frame for disability in Egypt revolved around charity instead of jobs or the integration of people with disabilities. In general, the development of a rights tradition or frame, and especially the extension of that frame to people with disabilities (Altman \& Barnartt, 1993) represent a big leap forward for disability activism (Barnartt $\&$ Scotch, 2000). So, even if it was only that a journalist applied that frame, it represents the beginning of a significant change in the frame through which disabilities were being viewed.

In sum, this paper has suggested that, although the two sets of protests may have arisen initially for different reasons, there may have been a spillover from the pro-Democracy protests to the disability protests. We cannot with certainty link the rise of disability protests and the discourse of rights to the pro-Democracy protests, because of the methodological limitations of this study. But we can propose that an as hypothesis requiring further research. It would be necessary to interview participants in the disability protests in order to gain stronger support for that hypothesis. 


\section{Notes}

1 Mahmoud (2012) indicates that protests occurred for over 3 months in 2010, but he does not specify the precise dates.

2 It may be that using one category called "rights" and another called "services" may not create fine enough distinctions in societies in which there is no clear civil rights tradition. Rather, it might be better to use several sub-categories within each category. This points to the problem of cross-cultural comparison, mentioned above.

3 As I have argued elsewhere (Barnartt, 2010), disability protests in other countries do not seem to be related to globalization or external economic and cultural trends spreading around the world.

\section{References}

Altman, B., \& Barnartt, S. (1993). Moral entrepreneurship and the passage of the ADA. Journal of Disability Policy Studies 4(1), 21-40.

Anderson, L. (2011, May-June). Demystifying the Arab Spring: Parsing the differences between Tunisia, Egypt, and Libya, Foreign Affairs.

Arafa, M. A. (2011). Towards a culture for accountability: A new dawn for Egypt. Forum on the January 25th Revolution. Indianapolis, IN: Indiana University School of Law.

Barnartt, S. (1992). Policy Issues in Disability and Rehabilitation in Developing Countries. Journal of Disability Policy Studies, 3(1), 45-65.

Barnartt, S. (1994). Action and consensus mobilization in the deaf president now protest and its aftermath. Research in Social Movements, Conflict and Change, 17, 115-134.

Barnartt, S. (2008). Social movement diffusion? The case of disability protests in the US and Canada. Disability Studies Quarterly 28(1). Retrieved from http://dsq-sds.org/

Barnartt, S. (2010). The globalization of disability protests, 1970-2005: Pushing the Limits of Cross-Cultural Research? Comparative Sociology 9, 222-240.

Barnartt, S., \& Rotman, R. (2007). Disability policies and protests in Israel. Disability Studies Quarterly 27(4).

Barnartt, S., \& Scotch, R. (2000). Disability protests: Contentious actions 1970-1999. Washington, DC: Gallaudet University Press.

Barral, C. (2007). Disabled persons' associations in France. Scandinavian Journal of Disability Research, 9(3-4), 214-236.

Beinin, J. (2009). Workers' protest in Egypt: Neo-liberalism and class struggle in 21st century. Social Movement Studie,s 8(4), 449-454.

Bugg, M. A. (2001). Claiming equality: South Africa's disability-rights movement within the nation's struggle for democracy. New Haven, CT, US. Retrieved from Dissertations \& Theses: Full Text database

Davies, J. (1963). Toward a theory of revolution. The American Sociological Review, 27(1), 5-19.

Disabled protest in Egypt continues. (2011, June 17). The Egyptian Gazette. Retrieved February 15, 2012, from LexisNexis Academic database.

Egyptian government bows to handicapped students. (1996, December 18.) Deutsche PresseAgenteur. Retrieved December 15, 2011, from LexisNexis Academic database.

Egyptian people with disabilities must not be forgotten. (2011, September 12). The Egyptian Gazette. Retrieved December 15, 2011, from LexisNexis Academic database.

Egyptian students demonstrate in support of handicapped colleagues. (1996, December 15). Deutsche Presse-Agenteur. Retrieved December 15, 2011, from LexisNexis Academic database.

Elshami, N. (2012, June 16). People with disabilities in Egypt overlooked and underestimated. Muftah. Retrieved from http://muftah.org/

Famous Streets Home for Angry Protesters. (2011, November 3). The Egyptian Gazette. Retrieved from http://213.158.162.45/ egyptian

Gamson, W. (1975). The strategy of social protest. Belmont, CA: Wadsworth.

Glover, J. (2010). The role of protest in Egyptian politics. Washington, DC: The George 
Washington University Elliott School of International Affairs.

Hayashi, R., \& Okuhira, M. (2001). The disability rights movement in Japan: Past, present and future. Disability and Society 16(6), 855-869.

Helplessness is the Keyword. (2011, November 14). The Egyptian Gazette.

Heyer, K. C. (2002a). The ADA on the road: Disability rights in Germany. Law and Social Inquiry, 723-762.

Heyer, K. C. (2002b). Rights on the road: Disability politics in Japan and Germany. Ph.D. dissertation, University of Hawai'i, United States. Retrieved from Dissertations \& Theses: Full Text database. (Publication No. AAT 3045427).

Heyl, B. (1998). Parents, politics and the public purse: Activists in the special education arena in Germany. Disability and Society, 13(5), 683-707.

Ismail, A. (2011, November 11). Disabled protesters suspend sit-in outside cabinet. Al Masry. Retrieved from http://almasryalyoum.com/

Klandermans, B. (1984). Mobilization and participation: social-psychological expansion of resource mobilization theory. The American Sociological Review 49, 583-600.

Klandermans, B. (1988). The formation and mobilization of consensus. In H. K. B. Klandermans, (Ed.), International Social Movement Research, Vol. 1 (pp. 173-196). Greenwich, CT: JAI Press, Inc.

Kriesi, H., Koopmans, R., Duyvendak, J. W., \& Guigni, M. (1997). New social movements and political opportunities in Western Europe. In D. M. Snow (Ed.), Social movements: Readings on their emergence, mobilization and dynamics (pp. 52-65). Los Angeles, CA: Roxbury Publishing Co.

Lipsky, M. (1968). Protest as a political resource. American Political Science Review, 62, 11441158.

Mahmoud, M. (2012, April 2). Egyptian bill aims to protect rights of special needs citizens. AlShorfa. Retrieved from http://al-shorfa.com

McAdam, D. (1982). Political process and the development of black insurgency, 1930-1970. Chicago, IL: University of Chicago Press.

McAdam, D. ( 1995). "Initiator" and "spin-off" movement diffusion processes in protest cycles. In M. Traugott, Repertoires and cycles of collective action (pp. 217-238). Durham, NC: Duke University Press.

McAdam, D., McCarthy, J. D., \& Zald, M. N. (1988). Social Movements. In N. J. Smelse, Handbook of Sociology (pp. 695-737). Beverly Hills, CA: Sage.

McCarthy, J., \& M. Zald, M. (1973). The Trend of Social Movements in America: Professionalization and Resource Mobilization. Morristown, NJ: General Learning Press.

McCarthy, J., McPhail C., \& Smith, J. (1996). Images of protest: Dimensions of selection bias in media coverage of Washington demonstrations, 1982 and 1991. American Sociological Review, 61(3), 478-499.

Meyer, D., \& Tarrow, S. (1998). A movement society: Contentious politics for a new century. In D. M. Tarrow (Ed.) The social movement society: Contentious politics for a new century, (pp. 1-28.). Lanham, MD: Rowman and Littlefield.

Meyer, D., \& Whittier, N. (1994). Social movement spillovers. Social Problems, 41(2), 277-298.

Morris, A. (1984). The origins of the civil rights movement: Black communities organizing for change. New York, NY: Free Press.

Mueller, C. (1997, October). International press coverage of East German protest events, 1989. American Sociological Review, 62, 820-832.

Olesen, T. (2005). The uses and misuses of globalization in the study of social movements. Social Movement Studies, 4(1), 49-63.

Oliver, M. (1990). The politics of disablement. New York, NY: St. Martins Press.

Oliver, M. (1996). Understanding disability: From theory to practice. New York, NY: St. Martins Press.

Olson, R. D, Penna, D., \& Veith, M. (2004). The evolution of the European disability movement. International Studies Association Annual Meeting. Montreal, Canada.

Opp, K. (1988, December). Grievances and participation in social movements. American Sociological Review, 53, 853-864.

Pfeiffer, D. (1988). Divisions in the disability community. Disability Studies Quarterly, 8(2), $1-3$.

Piven, F., \& Cloward, R. (1979). Poor people's movements: Why they succeed, how they fail. 


\section{Sharon N. Barnartt}

New York, NY: Random House.

Reynolds, N. (2006). Silent no more: Special needs people in Egypt. International Journal of Middle East Studies, 38(2), 237-238.

Rowles, M., \& Stretcher, K. (2011). Whose revolution is it, anyway? Social Policy, 41(4), 62-65.

Salam, Mohammed. (2010, March 23). Egypt's disabled look for protest victory. Bikya Masr. Retrieved from http://www.ikhwanweb.com/article.php?id=23827

Salem, Mona. (2010, May 6). Pavement is home for angry Egyptian protesters. Agence France Presse, Retrieved December 15, 2011, from LexisNexis Academic database.

Scotch, R. (1984). From good will to civil rights: Transforming federal disability policy. Philadelphia, PA: Temple University Press.

Scotch, R. (1988). Disability as the basis for a social movement: Advocacy and the politics of definition. Journal of Social Issues, 44(1), 59-72.

Slackman, M. (2010, April 10). Chants from street test Egypt's ruling party. The International Herald Tribune.

Smelser, N. (1962). Theory of collective behavior. New York, NY: Free Press.

Snow, D. A., Rochford, Jr., B. E., Worden, S. K., \& Benford, R. D. (1986). Frame alignment processes, micromobilization and movement participation. American Sociological Review $51,464-481$.

Snow, D., \& Benford, R. (1988). Ideology, frame resonance and participant mobilization. In B. Klandermans, H. Kriesi, \& S. Tarrow (Eds.), International Social Movement Research, vol. 1., (pp. 197-217). Greenwich, CT: JAI Press Inc.

Snow, D. A. and Benford, R. D. (1992). Master Frames and cycles of protest. In A. D. Morris \& C. M. Mueller, (Eds.), Frontiers in Social Movement Theory, (pp. 133-155). New Haven, CT: Yale University Press.

Snyder, D. A., \& Kelly, W. R. (1977). Conflict intensity, media sensitivity and the validity of newspaper data. American Sociological Review, 42(1), 105-123.

Tarrow, S. (1989). Democracy and disorder: Protest and politics in Italy 1965-75. New York: Oxford University Press.

Tucker, J. A. (2007). Local strategies in a global network: Disability rights advocacy in Jamaica. Dissertations \& Theses: Full Text database. Publication No. AAT 3292585. 